\title{
Journal of Applied Crystallography
}

Volume 47 (2014)

Supporting information for article: kk5173

Does the size of a crystal matter in an X-ray crystal structure analysis of a small molecule?

Seik Weng $\mathrm{Ng}$ and Seng Lim Tan 
Table S1 Refinement of $\mathrm{C}_{7} \mathrm{H}_{8} \mathrm{FN}_{3}\left(P 2_{1} / c\right.$ space group; $\left.\mu=0.36 \mathrm{~mm}^{-1}\right)$

\begin{tabular}{lllll}
\hline & & & & \\
Unit cell $\left(\AA,{ }^{\circ}\right)$ & $11.9470(8)$ & $11.9525(8)$ & $11.9359(7)$ & $11.9533(8)$ \\
& $5.5093(3)$ & $5.5111(3)$ & $5.5005(3)$ & $5.5087(4)$ \\
& $12.4564(7)$ & $12.4566(7)$ & $12.4375(7)$ & $12.4688(8)$ \\
& $91.712(6)$ & $91.699(5)$ & $91.776(5)$ & $91.699(6)$ \\
Volume $\left(\AA^{3}\right)$ & $819.51(8)$ & $820.17(8)$ & $816.17(8)$ & $820.7(1)$ \\
Size, mm & $0.71 \times 0.36 \times 0.18$ & $0.47 \times 0.40 \times 0.17$ & $0.34 \times 0.28 \times 0.17$ & $0.30 \times 0.25 \times 0.15$ \\
Crystal vol., mm ${ }^{3}$ & 0.0396 & 0.0241 & 0.0117 & 0.0090 \\
Eqiv. $r$ mm & 0.21 & 0.18 & 0.14 & 0.13 \\
min./max. trans. & $0.846-0.942$ & $0.874-0.945$ & $0.910-0.945$ & $0.915-0.952$ \\
(Multi-scan $\left.T_{\text {min }}\right)$ & $(0.788)$ & $(0.799)$ & $(0.869)$ & $(0.920)$ \\
No. reflns. & 1892 & 1892 & 1881 & 1894 \\
Av. $R_{\text {eqiv }}, \sigma\left(I / I_{\text {net }}\right)$ & $0.035,0.040$ & $0.037,0.040$ & $0.041,0.043$ & $0.041,0.048$ \\
No. $I>2 \sigma(I)$ reflns. & 1536 & 1513 & 1475 & 1475 \\
Av. $R_{\text {eqiv }}, \sigma\left(I / I_{\text {net }}\right)$ & 27.58 & 27.58 & 27.54 & 27.58 \\
$2 \theta_{\text {max }}$ & 0.035 & 0.036 & 0.036 & 0.037 \\
$R$ & $(0.0336 P)^{2}+0.4252 P$ & $(0.0383 P)^{2}+0.3747 P$ & $(0.0424 P)^{2}+0.3065 P$ & $(0.0367 P)^{2}+0.3187 P$ \\
Weighting & $-0.26-0.26$ & $-0.24-0.28$ & $-0.27-0.32$ & $-0.26-0.26$ \\
$e$ map, min./max. & & & & \\
& & & & \\
\hline
\end{tabular}

Table S2 Refinement of $\mathrm{C}_{20} \mathrm{H}_{25} \mathrm{Br}\left(P 2_{1} 2_{1} 2_{1}\right.$ space group; $\left.\mu=2.72 \mathrm{~mm}^{-1}\right)$

\begin{tabular}{lllll}
\hline & & & & \\
Unit cell $\left(\AA,{ }^{\circ}\right)$ & $5.6130(4)$ & $5.6011(3)$ & $5.6104(4)$ & $5.6112(4)$ \\
& $8.5301(5)$ & $8.5219(4)$ & $8.5238(4)$ & $8.5333(4)$ \\
& $31.435(2)$ & $31.474(1)$ & $31.496(2)$ & $31.439(1)$ \\
Volume $\left(\AA^{3}\right)$ & $1505.1(2)$ & $1502.3(1)$ & $1506.2(2)$ & $1505.4(1)$ \\
Size, mm & $0.85 \times 0.36 \times 0.22$ & $0.51 \times 0.39 \times 0.23$ & $0.44 \times 0.28 \times 0.22$ & $0.25 \times 0.20 \times 0.20$ \\
Crystal vol., $\mathrm{mm}^{3}$ & 0.0536 & 0.0293 & 0.0153 & 0.0073 \\
Eqiv. $r, \mathrm{~mm}$ & 0.23 & 0.19 & 0.15 & 0.12 \\
min./max. trans. & $0.251-0.601$ & $0.392-0.619$ & $0.460-0.633$ & $0.598-0.647$ \\
(Multi-scan $\left.T_{\text {min }}\right)$ & $(0.252)$ & $(0.696)$ & $(0.759)$ & $(0.869)$ \\
No. reflns. & 3488 & 3479 & 3486 & 3454 \\
Av. $R_{\text {eqiv }}, \sigma\left(I / I_{\text {net }}\right)$ & $0.044,0.078$ & $0.034,0.042$ & $0.047,0.068$ & $0.047,0.068$ \\
No. $I>2 \sigma(I)$ reflns. & 3007 & 3169 & 3018 & 3005 \\
2 $\theta_{\text {max }}$ & 27.57 & 27.59 & 27.60 & 27.60 \\
$R$ & 0.048 & 0.035 & 0.047 & 0.047 \\
Weighting & $(0.0335 P)^{2}$ & $(0.0336 P)^{2}+0.9819 P$ & $(0.0332 P)^{2}+1.2196 P$ & $(0.0332 P)^{2}+1.2196 P$ \\
Flack parameter & $0.01(1)$ & $0.01(1)$ & $0.02(2)$ & $0.02(2)$ \\
$e$ map, min./max. & $-0.84-1.06$ & $-0.67-0.96$ & $-0.96-1.13$ & $-0.97-1.15$
\end{tabular}


Table S3 Refinement of $\mathrm{Cu}\left(\mathrm{H}_{2} \mathrm{O}\right)_{2}\left(\mathrm{C}_{6} \mathrm{H}_{12} \mathrm{~N}_{4}\right)\left(\mathrm{C}_{7} \mathrm{H}_{3} \mathrm{~N}_{2} \mathrm{O}_{6}\right)_{2} \cdot 2 \mathrm{H}_{2} \mathrm{O}(C 2 / c$ space group; $\mu=0.97$ $\mathbf{m m}^{-1}$ )

Table S4 Refinement of $\left[\mathrm{SnCl}\left(\mathrm{H}_{2} \mathrm{O}\right)\left(\mathrm{C}_{6} \mathrm{H}_{5}\right)_{3}\left(\mathrm{C}_{10} \mathrm{H}_{8} \mathrm{~N}_{2}\right)\right]_{2}\left(C 2 / c\right.$ space group; $\left.\mu=1.19 \mathrm{~mm}^{-1}\right)$

$\begin{array}{lllll}\text { Unit cell }\left(\AA{ }^{\circ},{ }^{\circ}\right) & 15.5966(7) & 15.5993(5) & 15.5742(4) & 15.5844(7) \\ & 16.1294(6) & 16.1284(4) & 16.1161(4) & 16.1120(5) \\ & 20.4387(9) & 20.4476(7) & 20.4181(6) & 20.4375(9) \\ & 108.891(5) & 108.849(4) & 108.879(3) & 108.872(5) \\ \text { Volume }\left(\AA^{3}\right) & 4864.7(4) & 4868.6(3) & 4849.2(2) & 4855.9(3) \\ \text { Size, mm } & 0.91 \times 0.63 \times 0.13 & 0.61 \times 0.55 \times 0.13 & 0.33 \times 0.26 \times 0.15 & 0.22 \times 0.18 \times 0.14 \\ \text { Crystal } \text { vol., } \mathrm{mm}^{3} & 0.0426 & 0.0284 & 0.0096 & 0.0036 \\ \text { Eqiv. } r \text { mm } & 0.22 & 0.19 & 0.13 & 0.09 \\ \text { min./max. trans. } & 0.501-0.857 & 0.565-0.875 & 0.765-0.856 & 0.804-0.874 \\ \left.\text { (Multi-scan } T_{\min }\right) & (0.595) & (0.634) & (0.836) & (0.842) \\ \text { No. reflns. } & 5635 & 5640 & 5610 & 5627 \\ \text { Av. } R_{\text {eqiv }}, \sigma\left(I / I_{\text {net }}\right) & 0.034,0.032 & 0.038,0.026 & 0.034,0.023 & 0.061,0.044 \\ \text { No. } I>2 \sigma(I) \text { reflns. } & 4651 & 4804 & 4855 & 4352 \\ 2 \theta_{\text {max }} & 27.60 & 27.61 & 27.58 & 27.60 \\ R & 0.028 & 0.028 & 0.026 & 0.033 \\ \text { Weighting } & (0.0432 P)^{2}+6.3326 P & (0.0453 P)^{2}+5.7910 P & (0.0440 P)^{2}+7.5426 P & (0.0420 P)^{2}+8.9852 P \\ e \text { map, min./max. } & -0.67-2.56 & -0.70-2.96 & -0.40-2.68 & -0.65-2.96\end{array}$


Table S5 Refinement of $\mathrm{Pb}\left(\mathrm{NO}_{3}\right)_{2}\left(\mathrm{C}_{3} \mathrm{H}_{9} \mathrm{~N}_{3} \mathrm{~S}\right)\left(P 2_{1} / n\right.$ space group; $\left.\mu=16.4 \mathrm{~mm}^{-1}\right)$

\begin{tabular}{lllll}
\hline & & & & \\
Unit cell $\left(\AA,{ }^{\circ}\right)$ & $5.3641(2)$ & $5.3460(2)$ & $5.3522(2)$ & $5.3522(2)$ \\
& $13.8966(6)$ & $13.8593(5)$ & $13.8783(6)$ & $13.8826(6)$ \\
& $14.2315(6)$ & $14.1995(6)$ & $14.2186(6)$ & $14.2217(6)$ \\
& $100.132(4)$ & $100.138(4)$ & $100.048(4)$ & $100.075(4)$ \\
Volume $\left(\AA^{3}\right)$ & $1044.31(7)$ & $1035.64(7)$ & $1039.95(7)$ & $1040.41(7)$ \\
Size, mm & $0.61 \times 0.28 \times 0.10$ & $0.34 \times 0.27 \times 0.09$ & $0.25 \times 0.23 \times 0.10$ & $0.32 \times 0.08 \times 0.06$ \\
Crystal vol., mm ${ }^{3}$ & 0.0127 & 0.0061 & 0.0037 & 0.0012 \\
Eqiv. $r$ mm & 0.14 & 0.11 & 0.10 & 0.07 \\
min./max. trans. & $0.026-0.259$ & $0.034-0.282$ & $0.062-0.281$ & $0.112-0.423$ \\
(Multi-scan $\left.T_{\text {min }}\right)$ & $(0.006)$ & $(0.095)$ & $(0.266)$ & $(0.360)$ \\
No. reflns. & 2366 & 2384 & 2394 & 2396 \\
Av. $R_{\text {eqiv }}, \sigma\left(I / I_{\text {net }}\right)$ & $0.048,0.044$ & $0.062,0.046$ & $0.051,0.042$ & $0.042,0.040$ \\
No. $I>2 \sigma(I)$ reflns. & 2129 & 2144 & 2110 & 2092 \\
$2 \theta_{\text {max }}$ & 27.58 & 27.58 & 27.57 & 27.58 \\
$R$ & 0.029 & 0.027 & 0.023 & 0.040 \\
Weighting & $(0.0346 P)^{2}$ & $(0.0272 P)^{2}$ & $(0.0196 P)^{2}$ & $(0.0171 P)^{2}$ \\
$e$ map, min./max. & $-3.54-0.93$ & $-2.27-1.13$ & $-1.48-0.94$ & $-0.93-1.14$ \\
& & & & \\
\hline
\end{tabular}




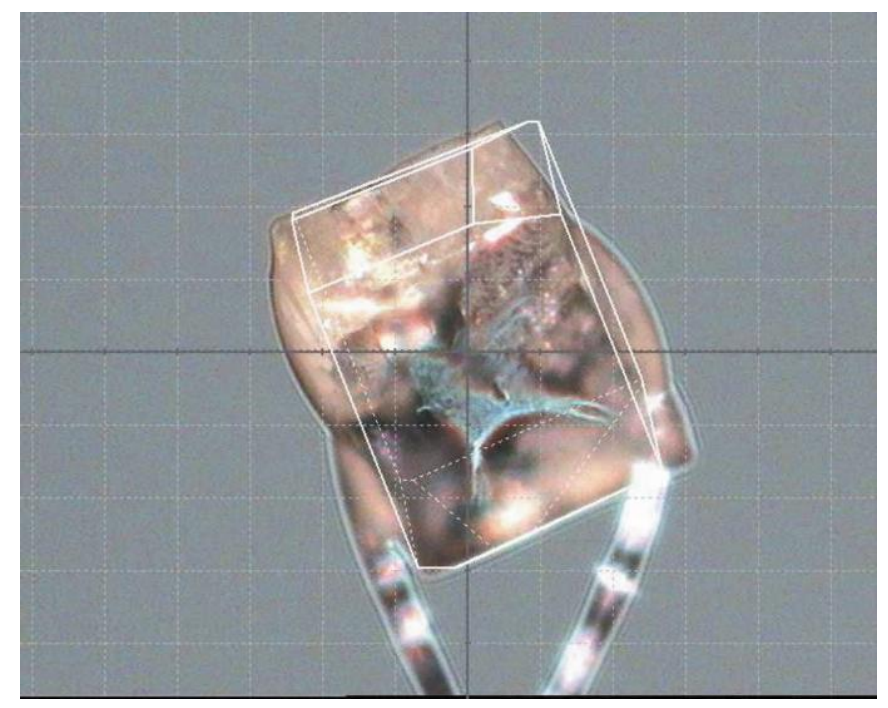

Figure S1 The huge crystal used for measuring (I). One square grid is $0.1 \times 0.1 \mathrm{~mm}$.

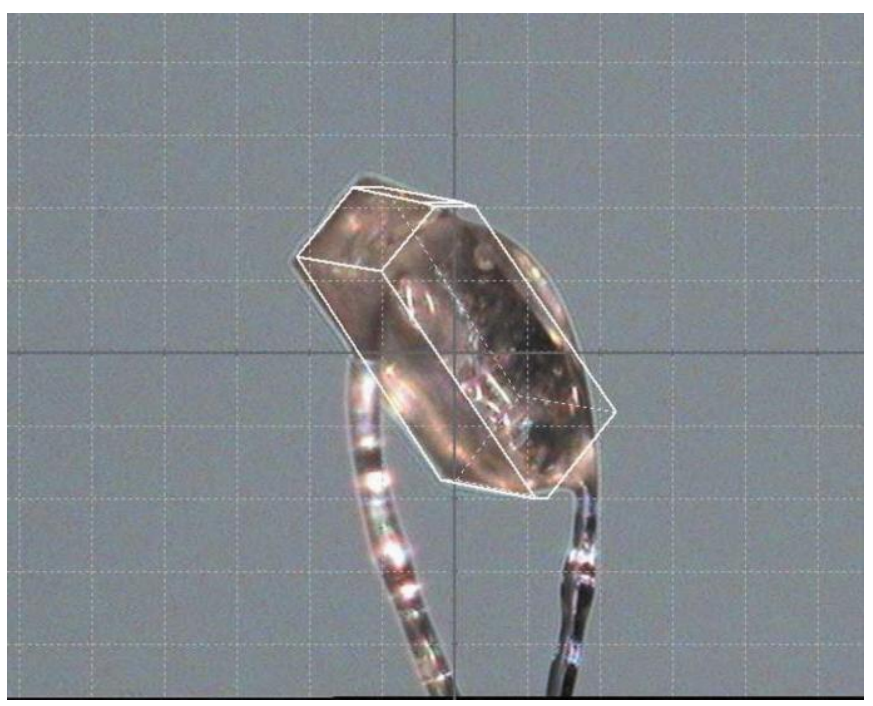

Figure S2 The large crystal used for measuring (I). One square grid is $0.1 \times 0.1 \mathrm{~mm}$.

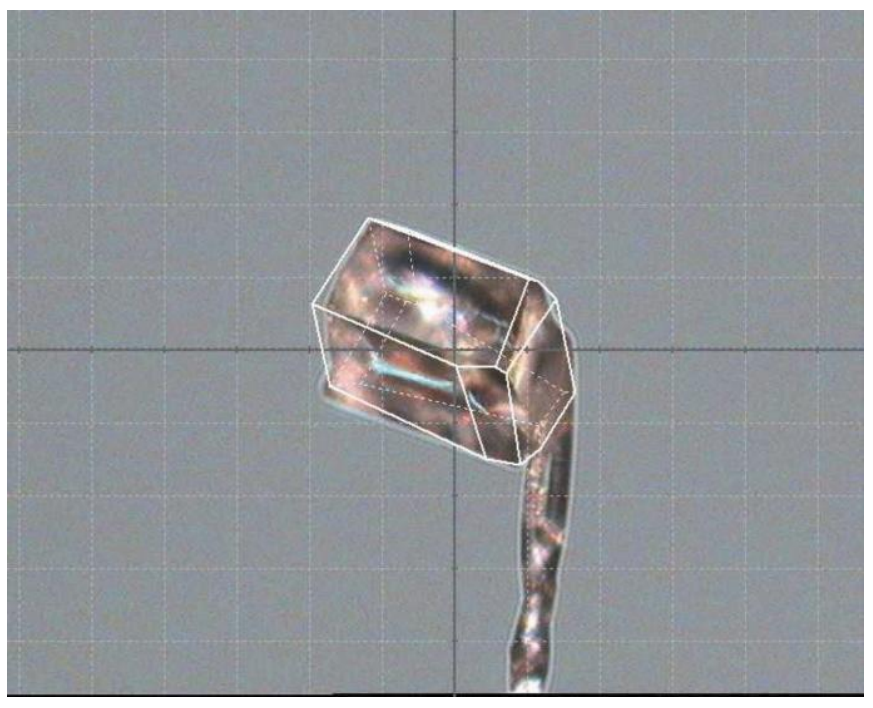

Figure S3 The medium crystal used for measuring (I). One square grid is $0.1 \times 0.1 \mathrm{~mm}$. 


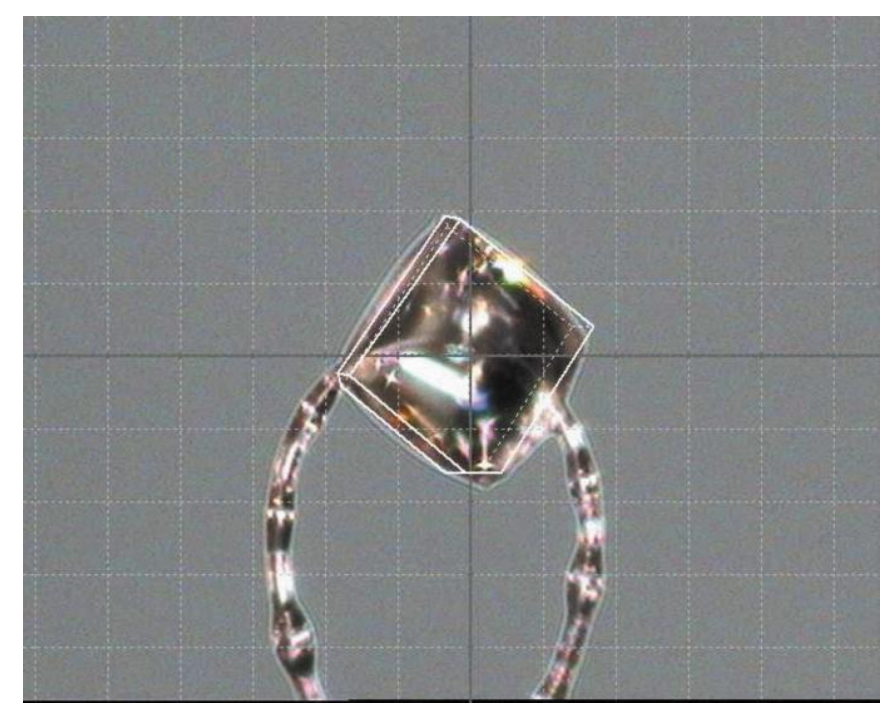

Figure S4 The small crystal used for measuring (I). One square grid is $0.1 \times 0.1 \mathrm{~mm}$.

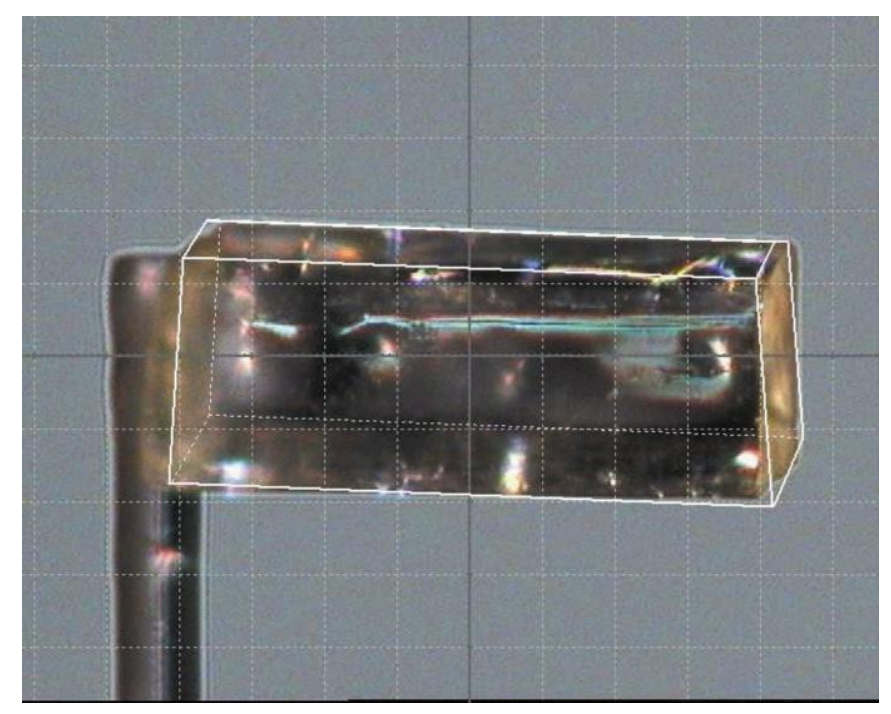

Figure S5 The huge crystal used for measuring (II). One square grid is $0.1 \times 0.1 \mathrm{~mm}$.

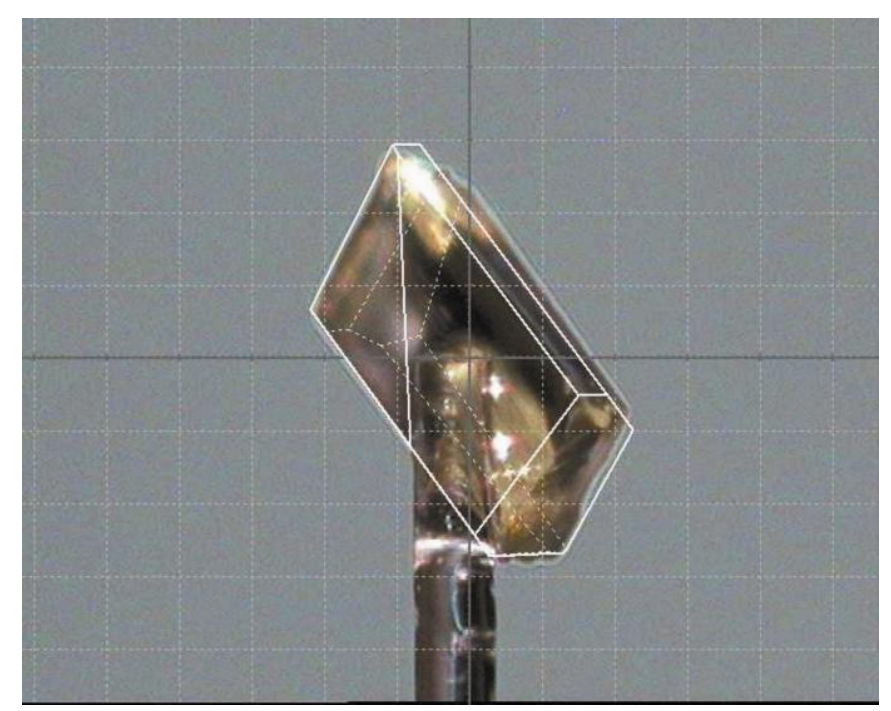

Figure S6 The large crystal used for measuring (II). One square grid is $0.1 \times 0.1 \mathrm{~mm}$. 


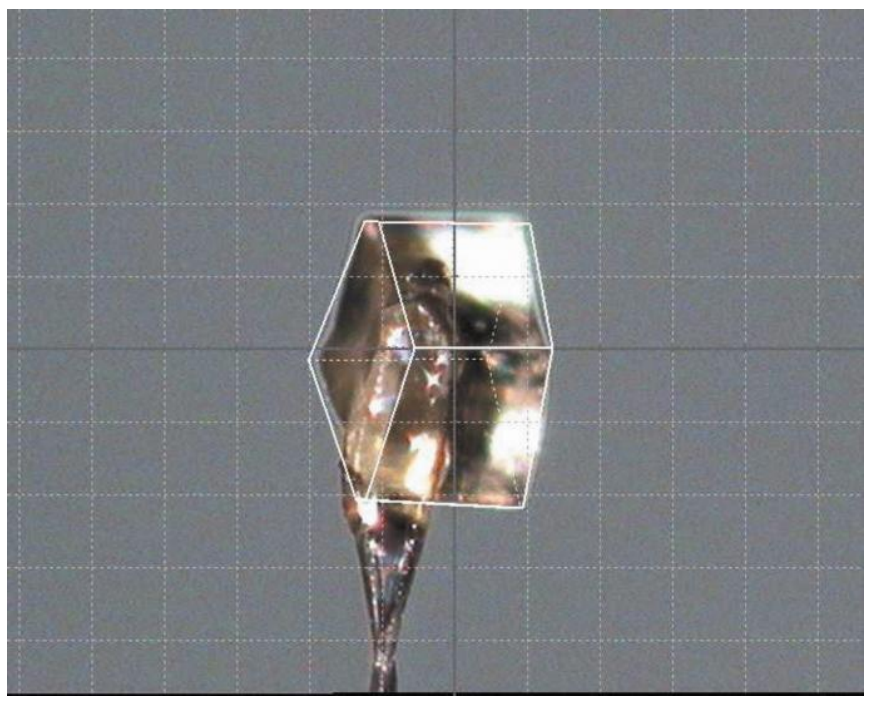

Figure S7 The medium crystal used for measuring (II). One square grid is $0.1 \times 0.1 \mathrm{~mm}$.

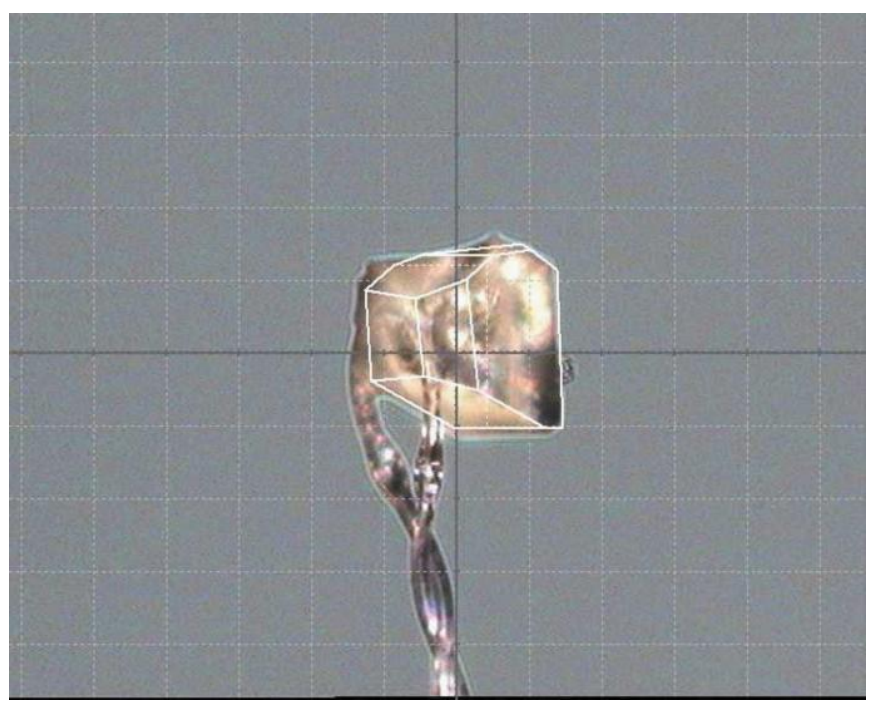

Figure S8 The small crystal used for measuring (II). One square grid is $0.1 \times 0.1 \mathrm{~mm}$.

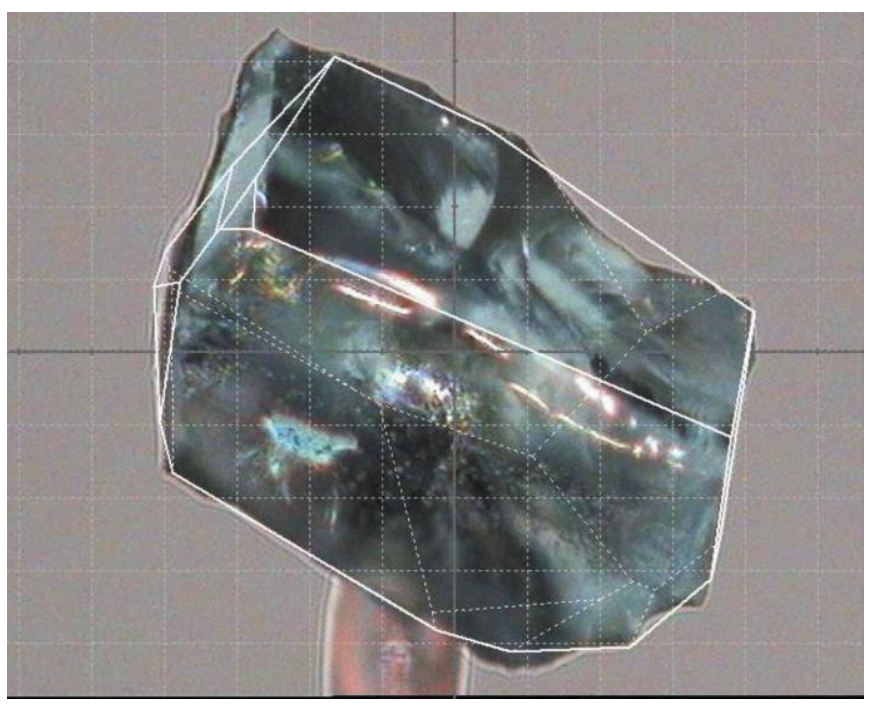

Figure S9 The huge crystal used for measuring (III). One square grid is $0.1 \times 0.1 \mathrm{~mm}$. 


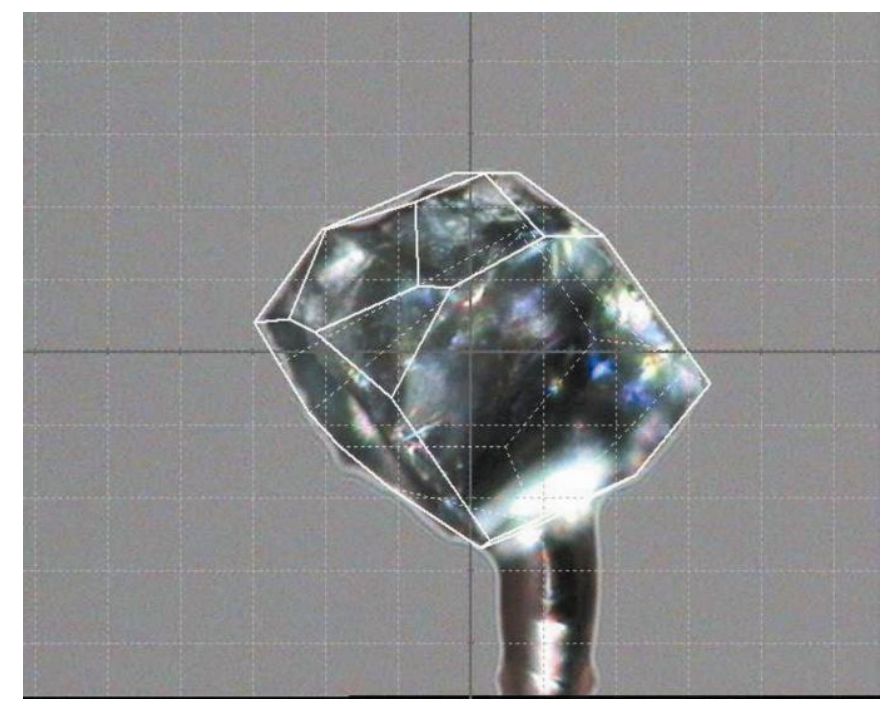

Figure S10 The large crystal used for measuring (III). One square grid is $0.1 \times 0.1 \mathrm{~mm}$.

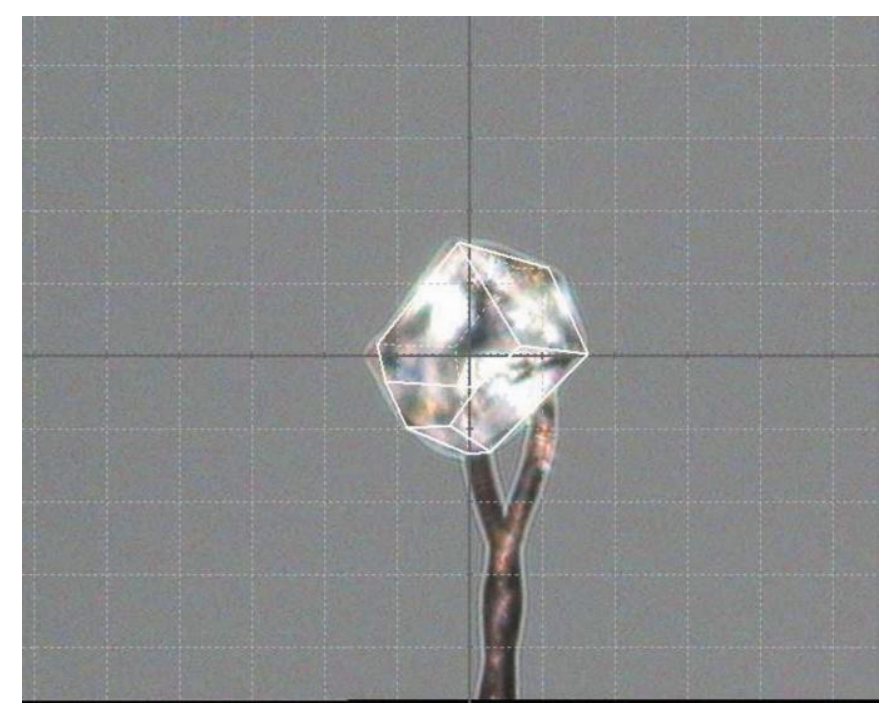

Figure S11 The medium crystal used for measuring (III). One square grid is $0.1 \times 0.1 \mathrm{~mm}$.

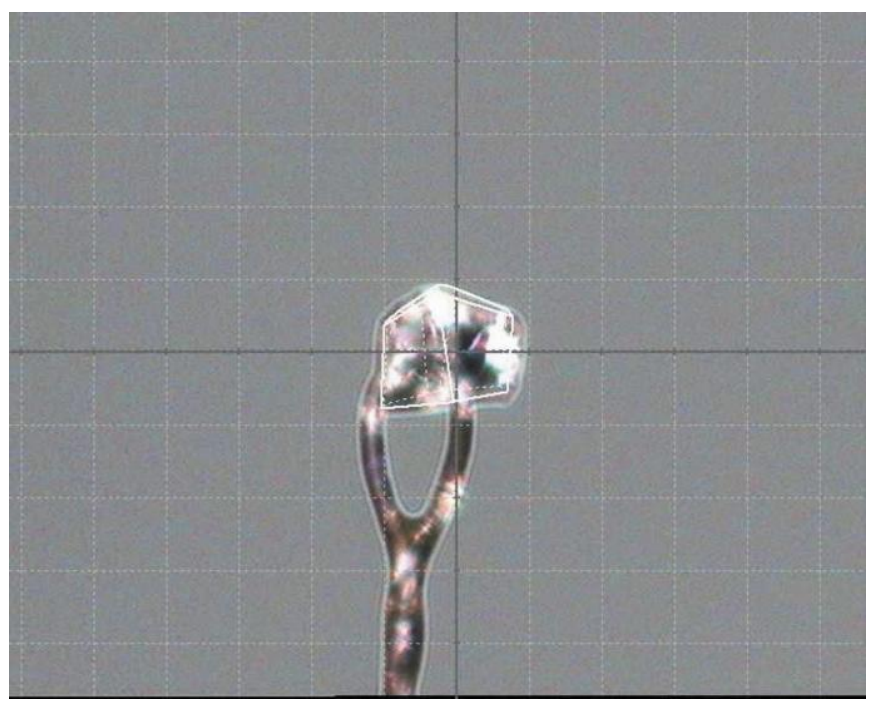

Figure S12 The small crystal used for measuring (III). One square grid is $0.1 \times 0.1 \mathrm{~mm}$. 


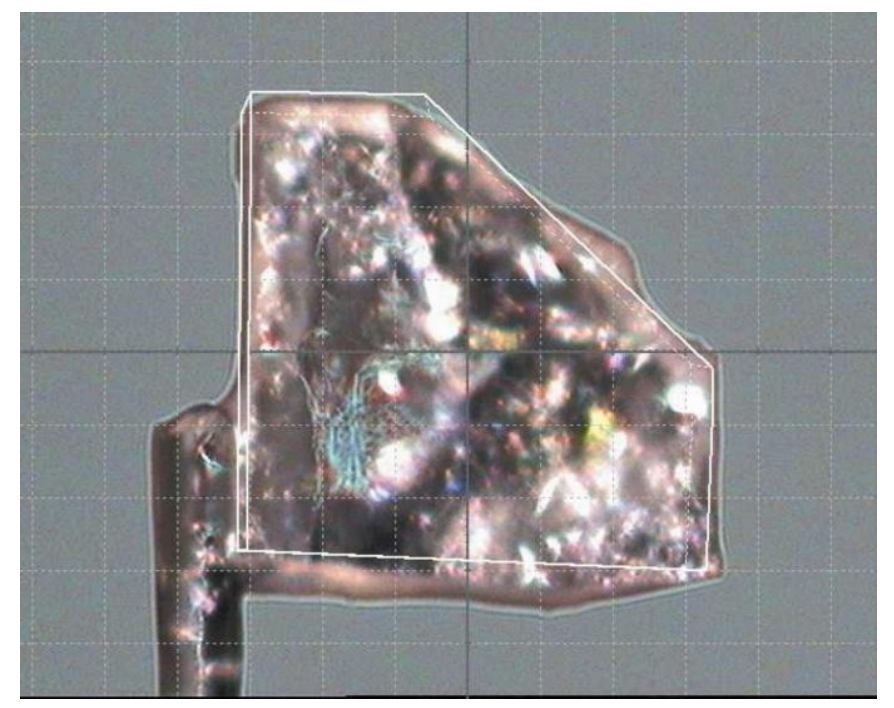

Figure S13 The huge crystal used for measuring (IV). One square grid is $0.1 \times 0.1 \mathrm{~mm}$.

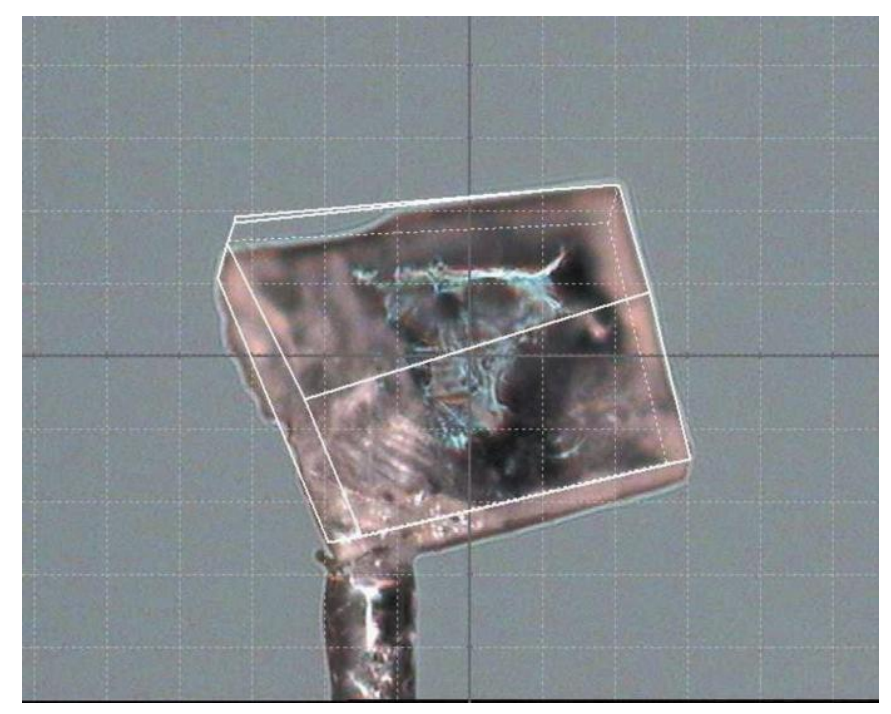

Figure S14 The large crystal used for measuring (IV). One square grid is $0.1 \times 0.1 \mathrm{~mm}$.

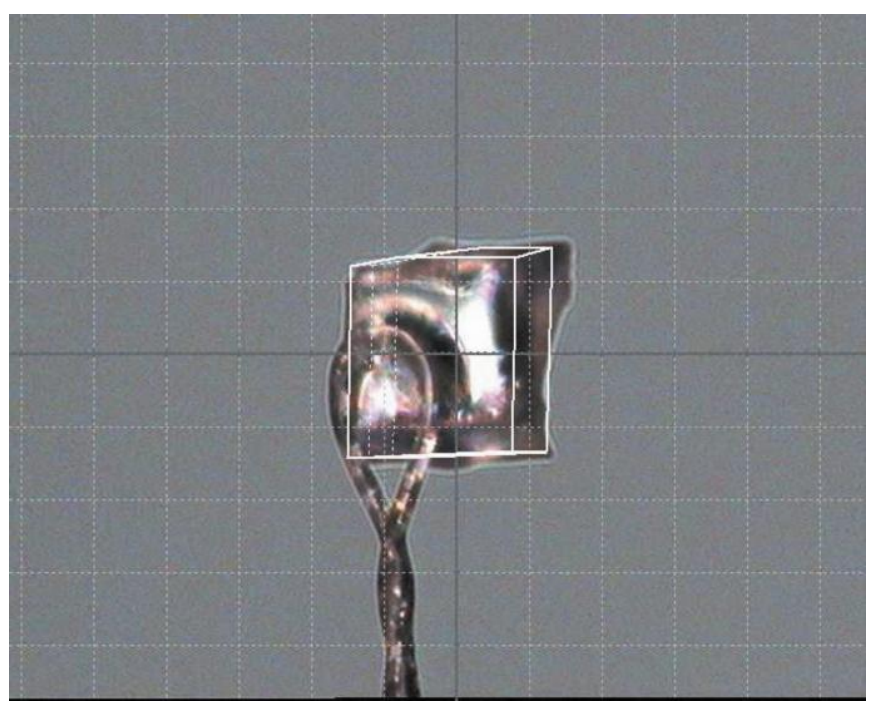

Figure S15 The medium crystal used for measuring (IV). One square grid is $0.1 \times 0.1 \mathrm{~mm}$. 


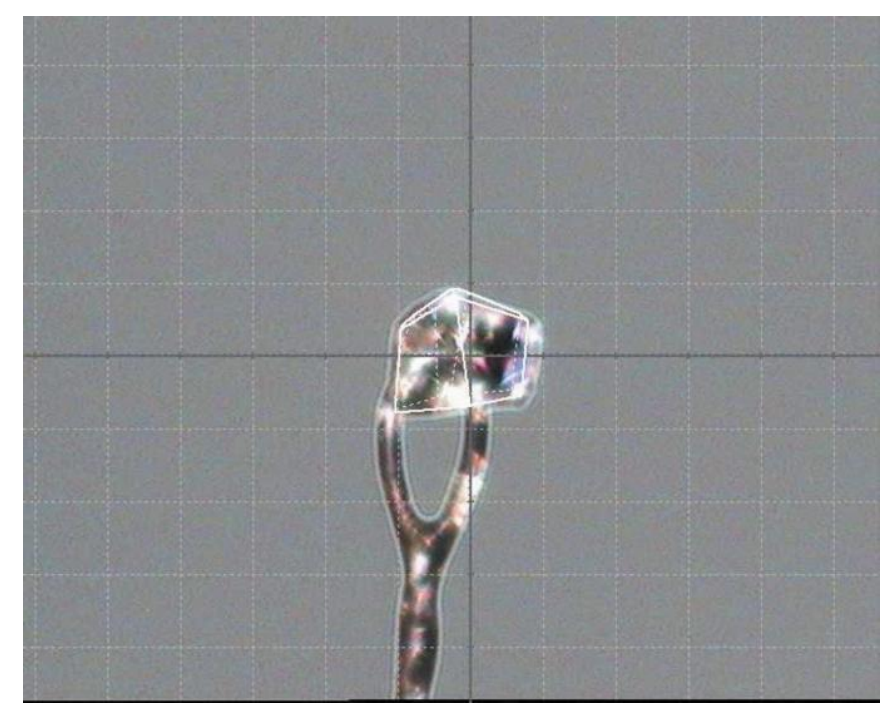

Figure S16 The small crystal used for measuring (IV). One square grid is $0.1 \times 0.1 \mathrm{~mm}$.

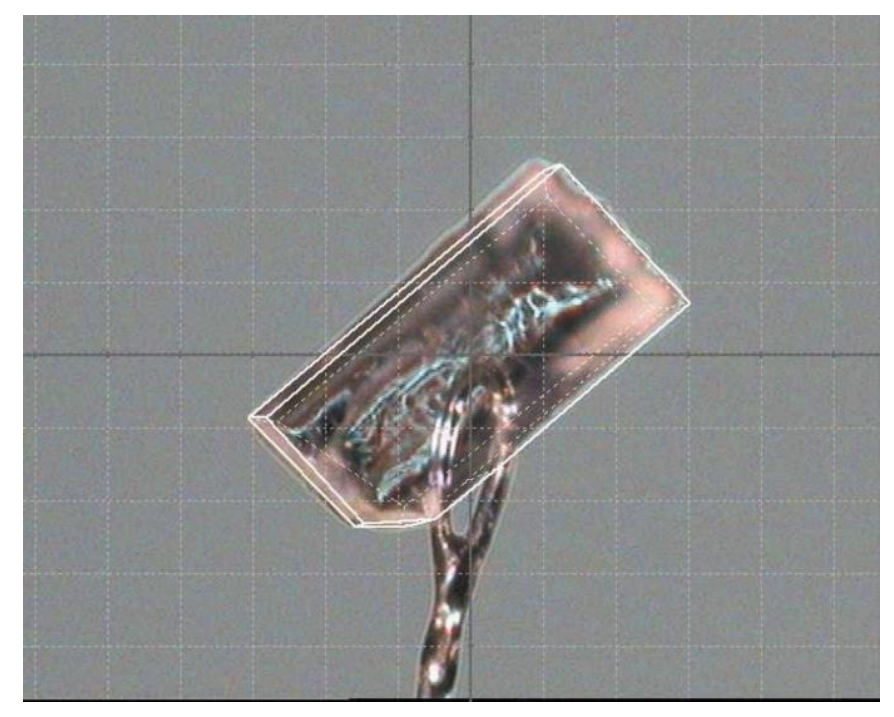

Figure S17 The huge crystal used for measuring (V). One square grid is $0.1 \times 0.1 \mathrm{~mm}$.

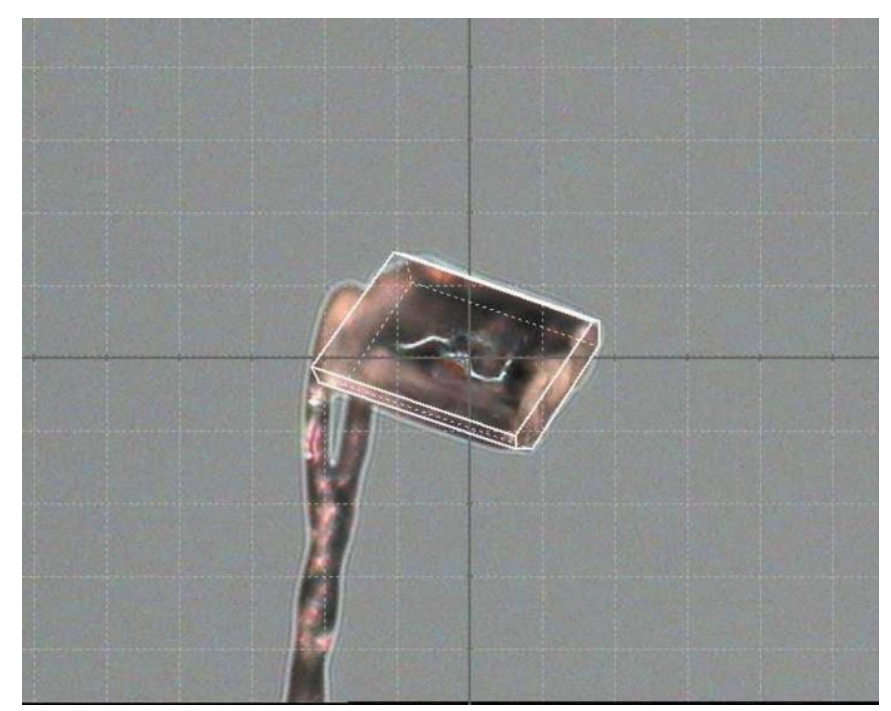

Figure S18 The large crystal used for measuring (V). One square grid is $0.1 \times 0.1 \mathrm{~mm}$. 


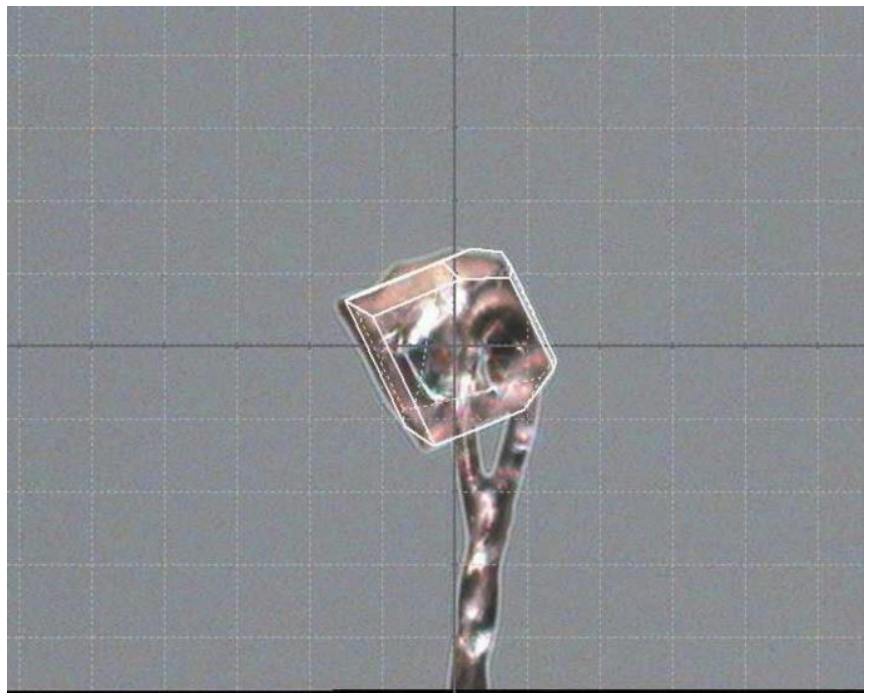

Figure S19 The medium crystal used for measuring (V). One square grid is $0.1 \times 0.1 \mathrm{~mm}$.

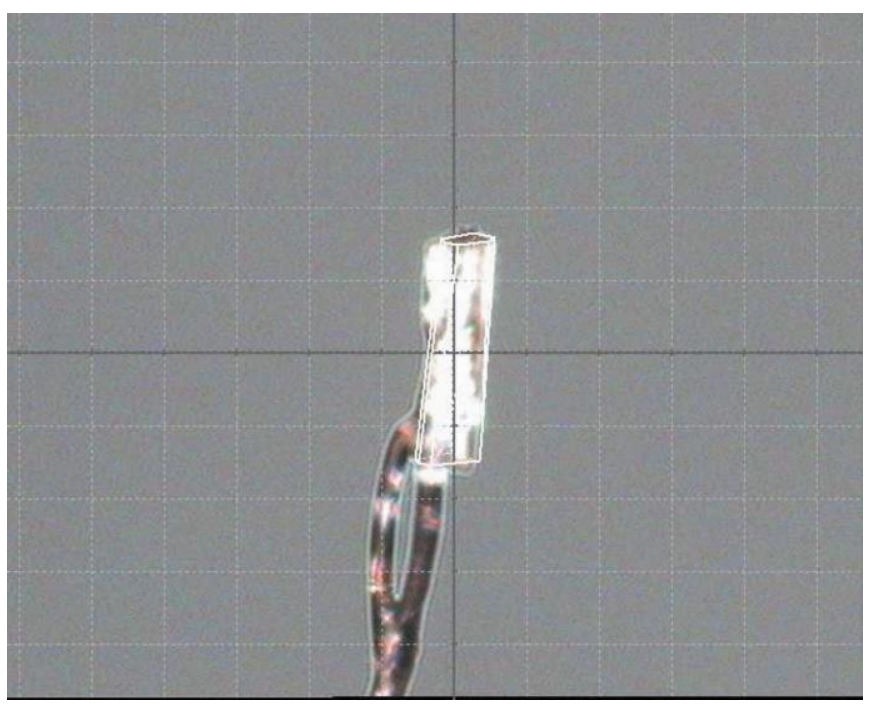

Figure S20 The small crystal used for measuring (V). One square grid is $0.1 \times 0.1 \mathrm{~mm}$.

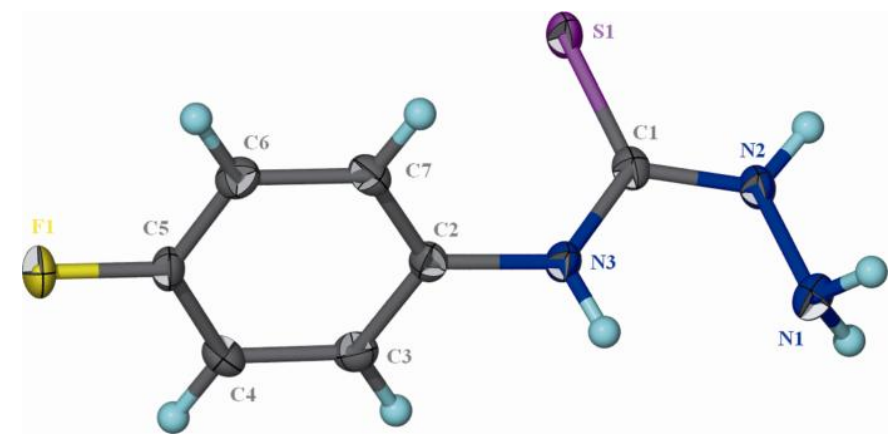

Figure S21 70\% Probability ORTEP (Barbour, 2001) plot of the refinement of the crystal structure of (I) from measurements on the huge crystal shown in Figure S1. 


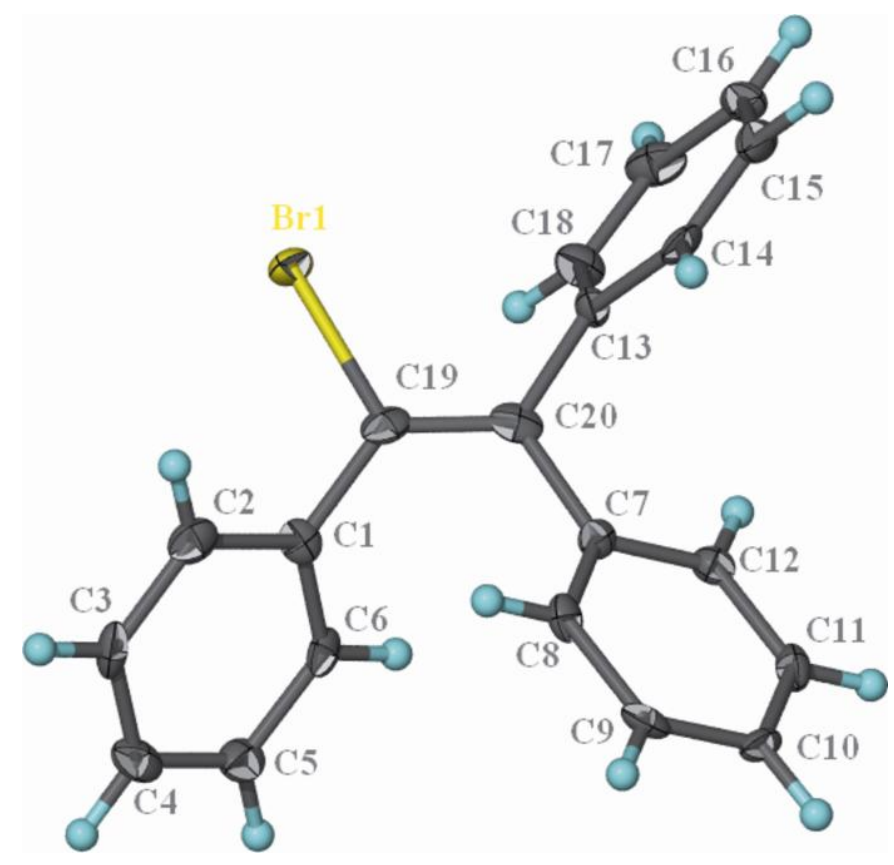

Figure S22 70\% Probability ORTEP (Barbour, 2001) plot of the refinement of the crystal structure of (II) from measurements on the huge crystal shown in Figure S5.

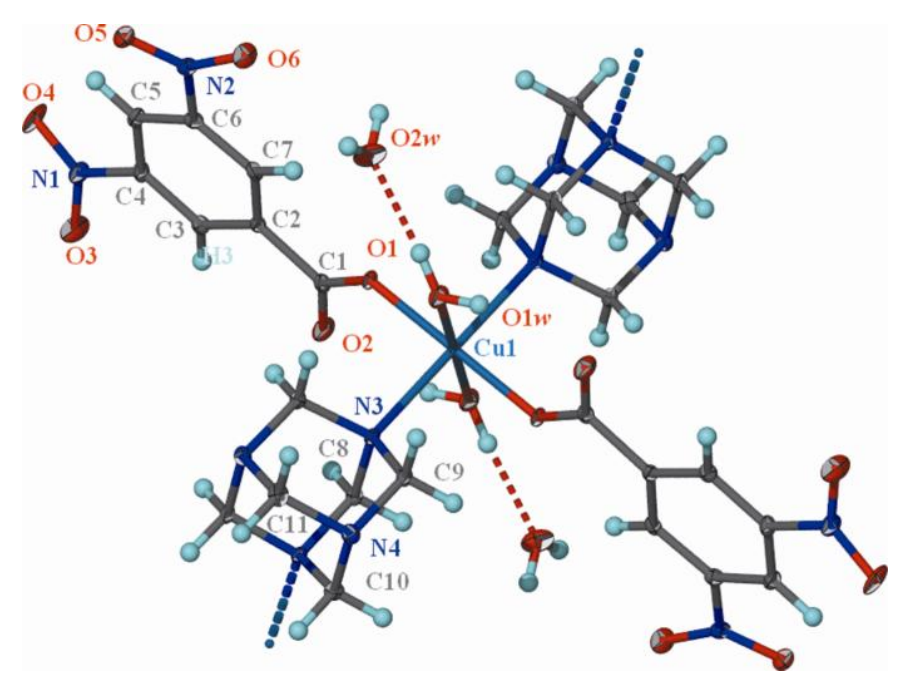

Figure S23 70\% Probability ORTEP (Barbour, 2001) plot of the refinement of the crystal structure of (III) from measurements on the huge crystal shown in Figure $\mathbf{S 9 .}$ 


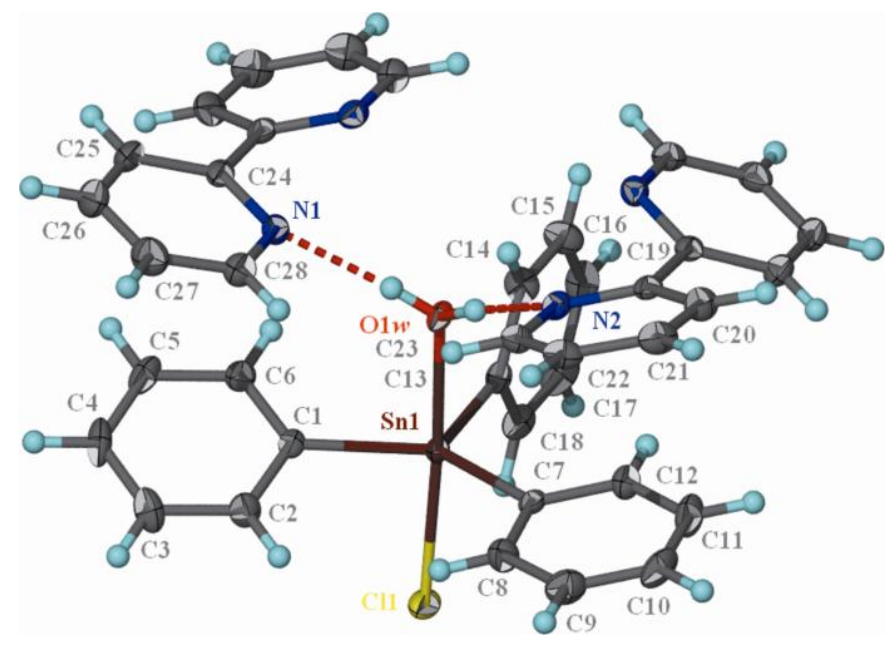

Figure S24 70\% Probability ORTEP (Barbour, 2001) plot of the refinement of the crystal structure of (IV) from measurements on the huge crystal shown in Figure S13.

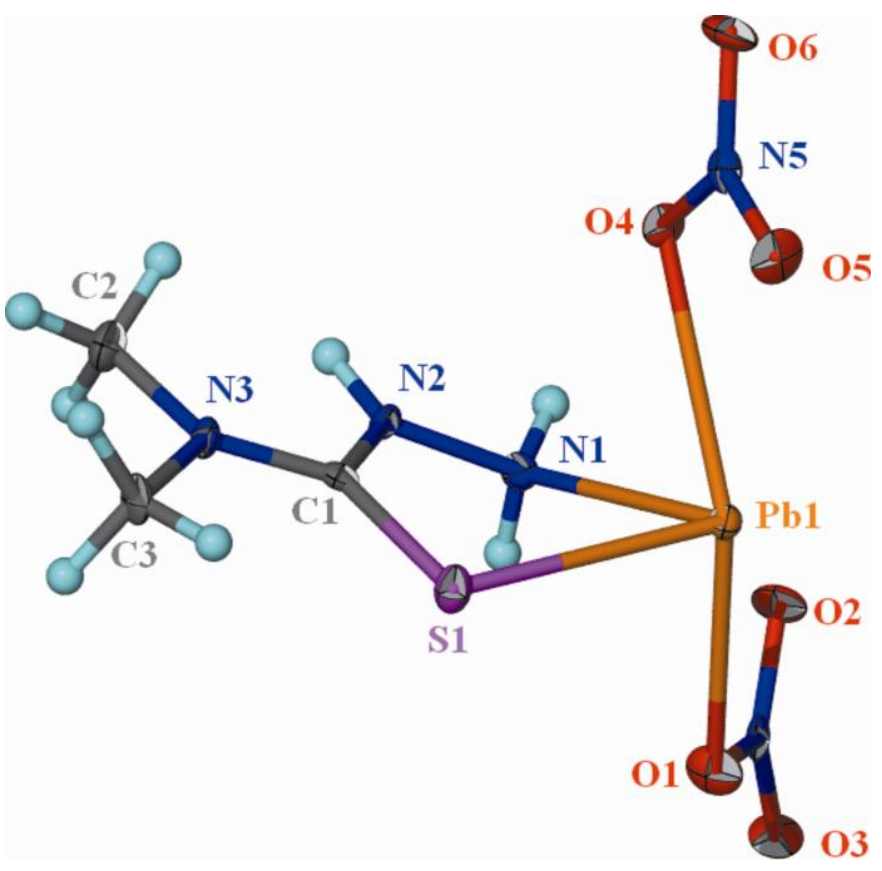

Figure S25 70\% Probability ORTEP (Barbour, 2001) plot of the refinement of the crystal structure of (V) from measurements on the huge crystal shown in Figure S17. 